\title{
POLITICAL ECONOMY APPROACH TO ENVIRONMENTAL EDUCATION
}

\begin{abstract}
The paper discusses the implications of Political Economy Approach to Environmental Education. It contrasts the orthodox, liberal economy approach with the radical political economy approach to the utilization of environmental information for the education of the masses. It examines the implications of politinal economy approach to environmental problems of health, population, and development, and shows llow a small percentage of world population found in developed economics is consuming a large part of world resources. It argues that given the division of the world into poor and rich countries, environmental problems will continues to resist superficial solutions, and the problems facing African countries in term of health, population and development will remain unsolved. There is need to consider seriously the radical approaches and solutions.
\end{abstract}

Keywords: Political economy, environmental degradation, Environmental education, capitalistexploitation, Population, development and health.

POLITICAL ECONOMY APPROACH TO ENVIRONMENTAL EDUCATION INTRODUCTION AND BACKGROUND

Since the arrival of Erivironmental Education in the Institute of Education, University of Calabar nearly twelve years age through World Wild Fund for nature (WWF) and (NCF) Nigerian Conservation Foundation, Environmental Education has penetrated into the Curriculum of many Universities and Colleges of Education. It is therefore gradually becoming a generally accepted discipline. Since its inception, it has tried to maintain it existence by drawing strength from divers sources including education itself. Geography, Geology, Physic, Chemistry, Medicine and Sociology. Even Business Management has contributed to the development of Environmental Education as a discipline. These significant inputs are probably due to inter-disciplinary and integrative nature of Environmental Education. They demonstrate the fact that Environmental Education is a multidimensional discipline which can be approached from different perspective. That is probably, why, many disciplines are at home with Environmental Education.

This paper is an attempt to present a political economics approach to Environmental Education. There is already a discipline called Environmental Economics which seeks to apply micro and macro-economic principles to problems of environmental. management and resources allocation. However, not many

people have gone beyond the orthodox economic analysis of environmental problems to the serious application of political econorny to the analysis of the same problem (Marx, 
;973a; 1976b; Colin and Roy, 1980).

This paper attempts to do this. It raises the following fundamental questions:

1. What is political ecorromy and why is it different from orthodox economics?

2. What specifically does political economy approach mean, and what are emphasized in this approach?

3. Given what this approach emphasizes, what will be its focus in the study of;

i) Population

ii) Health and

iii) Environmental issues?

b) What kind of policy outputs will be expected to be generated by application of this approach to Environmental Education?

4. What capabilities are expected from those who follow the political economy approach?

It is the purpose of this paper to attempt answers to these questions. The paper argues that despite various approaches to the study of environmental problems and issues that are in existence today, the political economy approach goes shallow analysis, naive and superficial strategies of environmental control to the fundamental causes of environmental disorganization.

\section{POLIT'CAL FCONOMY AND ORTHODOX ECONONICS}

Economics is sometimes defined as the science which studies human behaviour in relation to scares means which has alternative uses (see Samuelson, 1983; Lipset, 1960). This definition is accepted by capitalist econornists as fundamental to their discipline. The definition emphasizes human behaviour viewed from rational basis and decisions over means that are held to have alternative uses in the face of scarcity. It therefore directs the economists to specify economic behaviour under scarcity considerations using various tools of statistics and mathematics. This defintion is severely criticized by radical econonists who asserted that the economist does not study wealth as alternative uses in the face of scarcity (Abalkin, L:; Dzaarason, S; Klikov, A, 1993).

For radical economists, economics is the science that studies social relations which human beings form when they enter into production relations leading to production, distribution and consumption of goods and services. It should be noted that the emphasis is on production relations and not on choice of scare means which has alternative uses (lipset, 1960). What is production relation? People enter into certain relationship with each other when they produce goods and services. The most important relationship, however, is relationship in the ownership of the means of production. Relationship in the means of production defines, who owns capital, land and raw materials for production; who directs what is to be produced, and who owns only labour power.

Those who own capital and land are called capitalists and land-lords, and those who own only their labour power whether physical or mental are called labourers or workers. There are also those found in rural area who are engaged in farming activities on rented and communal lands and who are concerned, first with production of what they need and can consume while selling the surplus to the villages market. These people are called peasants excluding land owners in the rural areas (Martin, 1988).

As is well known; ownership of means of production always entitles the owners to claim some cost. Capitalist and raw material owners claim profit for the right of owning such thing, while land owners claims are based on production of excess on land owned and excess of capital owned. The workers who, of course, are in majority own nothing except their 
labour power. The wages paid to these workers are not fixed according to their needs but according to interaction of demand and supply in the labour marke ${ }^{\circ}$. According to this interaction, if the workers are too many, their wages only rise according to the whim of the capitalist.

It should be carefully noted that without production of excess above what was used in production, profit can not be derived, rent can not be derived, interest on capital cannot be paid and wages can not be paid. Therefore. wages, interest, profit and rent are collectively called surplus value produced by the active ingredient in production, namely, the workers and the peasants. The capitalist, knowing this, manipulates labour time in such a way that exploitation of the working class is intensified. With the coming of sophisticated technology, the exploitation of the worker is increased, and although many workers are thrown out of job, the size of surplus vales is vastly increased because of application of new technology and the improvement in workers skills. It is this surplus value that is often referred to as Gross National Product (GNP) by economist. They are particularly interested in increasing the quality of surplus value, and it is true to say that, the size of the surplus value indicates the formal states of the wealth of a given nation and that is what they referred to as GNP. This quantity however is an illusion. The radical scholars are insisting that:

1. man is the most important factor in any productive process.

2. the improvement in the quality of workers in terms of skills, knowledge and attitude increases the possibility of producing more surplus value.

3. that the bulk of surplus value so produced could have been made available to the total population producing it if ownership of means of production is not limited to few hands.
4.

that many social and environmental problems arise from the fact that production relation, in a capitalist society, are not planned and coordinated to take into consideration:

a) Equitable distribution of surplus value.

b) The investment of surplus value into organization of social production and restructuring of the environment; and

5. that no lasting solution to environmental disorganization, population and health problems is possible without a complete revolutionary organization of social production and distribution of social product and (Marx, 1973; Dear; 1986).

\section{POLITICAL ECONOMY APPROACH AND ITS EMPHASIS}

Given this theory, we then ask what does political economy approach emphasizes?

Political economy approach emphasizes production relations, production of surplus value, distribution and consumption of surplus value and the problem of class conflicts in a society structured in such a way that majority of the people have no control over the surplus value they produce. This approach calls attention to the fact that, without human beings no value can be produce in society, and therefore, the quality of the masses of the people, their access to education, the amount of surplus value they share, their class position in society, their cultural perspective and their ideological orientation are the most important variables determining a given society and its environment. If surplus value produced in society is monopolized by a small percentage of pecple who live in affluence and who therefore control societies' abundant resources and technology, while the rest of the population are disinherited, then the seed of social conflict, 
poverty, disease and disorientation is thereby assured. Today, in any serious analysis of society and its environment, political economy looks at who is producing what and with what means, who is consuming what in terms of surplus value, what size of the population can effectively reproduce itself and what part cannot reproduce itself because of serious deprivation of access to societies surplus value. These are the areas which political economy emphasizes (Bongaarts, 1996; Browb, 1981; Dear, 1980).

RADICAL FOCUS ON POPULATION, HEALTH AND ENVIRONMENTAL ISSUES

What does this theory deny? The theory denies some of followings by both environmentalists and orthodox Environmental Economists:

1. That in a class society where production resources are controlled by the few, environmental problems do have neutral solution but not class solution. In other words if the peasants are allowed to advance a solution to the problem of deforestation, their solution will be different from those of the capitalists or the transnationals. The workers will advance a different solution while the industrialists will also have a different solution. There is therefore, no solution in general apart from specific solutions rooted in the class nature of those who are involved. Not to understand this fact is to be puzzled by the numerous solutions offered of environmental problems that do not produce significant result (Colin, and Roy, 1987); Goldtarb, 1997; Dear, 1986).

2. The theory denies the effectiveness of exclusive physical approach to environmental problems. Any attempt that tries to solve environmental probiam by taking more plysical actions, restructuring physical hayout or physical space for instance, or sturying only physical phenomena and nocess will not succed. This is because, the environment in isolation 10 man, and ion relation to production is mearingless (Samoff, 1994).

3. The theory further denies that, such concepts like over-population, underpopulation, poverty, health capabilities of population, erosion, deforestation, bush-burning do not have significant meaning without being situated within a given class relations and socio-cultural variables ISminov,Golosov, Maximova, $1981)$.

4. The theory denie: that, environmental analysis is inseperable from analysis of production and consumption of what society is producing, but affirm that an understanding of the class structure of society, the orientations of each class to environmental utilization, the sociocultural dimensions of issues must all be taken into consideration when searching for effective solution to these problems (Reitsma, 1982; Mertin, 1988; Wottenberg, 19701.

A. POPULATION

We have already observed that, in a class society people complete to conirol surplus value. Because of certain historical factors and ownership of wealth patterns a large part of any given population are disinherited from control of surplus value and therefore are thrown into abject poverty, while five percent of the population consume the resources of society. In the face of this fact what does Gross National Product (GNP) represent but fictions quantify used in deceiving the people that wealth is either growing or diminishing for the entire population? 
In a class society, a condition of over-population implies a situation where majority of the people are un-employed and where a sizeabie population can not reproduce themselves given available esources in society, that section of society are deprived access to surplus value and therefore impoverized. When people have no access to utilize societies' resources and when what whey produce cannot be consumed by them because of their poverty and low demand capability, then we can affirm that, the quality of life in that population in indeed very lot (Boserup, 1996). It is on this basis that radical theorists insist that poverty alleviation programmes; better-life for rural women, population control strategies are ways of putting cats before the horse rather than effective approaches to solution of population problems. Moreover, it should be noted that, the world can now be divided into rich and poor countries have succeeded in making poor countries dependent upon them (Dear, 19801. The rich countries consume three quarters of world produced surplus value, while the poor countries labour unsuccessfully to produce themselves in a condition of over-burden debt and on the basis of one third of the world surplus value. Therefore, the productive capacities of the population of the third world countries are indeed very low.

\section{B HEALTH}

What can we then say of such over-stressed population? Deprived of available surplus value, having little or no share in land and forest resources, having little or no technology and highly ignorant of advances in medical science and unable to pay for high cost of hospitalization, the population wallow in poverty, disease and slum, it is under these conditions that, the immunity system of population of many countries including Nigeria have aimost collapsed making them to many diseases, including HIVIAIDS. Affluence countries, it must be noted, have significantly high healthy population, and it would appear the richer an individual in a given society the more likely he will adopt family planning strategies. The poor who place high value on children continues to reproduce themselves in large numbers and with such reproduction their poverty is increased. (Brown, 1981; Goldtarb, 1997).

\section{ENVIRONMENTAL ISSUES}

The followings are said to be problems facing many communities today over-population, gender inequality, pollution, deforestation, erosion, and desertification. We must have the courage to raise the question: What are the origin of these problem? Who is specifically involved in producing and accelerating them? No one can answer these questions without reference to the class structure of society, the control of the means of production including technology; and the form of distribution of surplus value. In the rich countries where the capitalists have control sophisticated technology,. massproduction in large scale industries have produced pollution and ozone depletion. (Meadows, 1972, Jones, 11972).

Generally, the resources used in these industries are the raw material from the poor countries. And, it poor countries grow poorer, burdened by debt servicing. Their poverty, however, also compel a large population in the poor countries to further stress their slender resources by cutting down tress, rivers 
and streams and over cultivation of the available soil. (Colin and Roy, 1987; Brown, 1981).

In the face of necessities, class nature, and surplus value deprivation, such concepts like environmental awareness, population control, poverty alleviation, pollution eradication have little or no meaning and appeal. Programmes that are directed towards mere increasing of awareness that constantly urge people to adopt family planning; that urge people to become aware of environmental problems are not realistic indeed, because the consciousness of people is determine by their social being and not by social awareness alone.

Are these analysis supported by some fundamental principles? Yes, they are supported by some principles.

1. The Principle of Externalities - Orthodox environmental economists have arrived at the principle of externalities. - This principle specifies that any activity within the environment which, though, positively enjoyed by the source of the activity, nevertheless, impacts on a second party negatively without commensurate cost is an externality. People are acting in the environment and they are enjoyed the results of their actions. But their action, also produce unintended consequences which affect others negatively. These negative unintended consequences are what are called externality (Picket and Singer, 1990; Dumont, 1988). The Alhaji who over grazes a given environment wills his cows to earn super profit when he sells the cows. But he does not pay for the grass and he does not provided part of the profit or regressing the environment. He has exposed others to problems of desertification and even drought due to over grazing. The transnational which through oil exploration allows oil to spill over a fishing community's river may pay compensation to chers who will consumed the same without investing it for regeneration of the river. The interpretation given to externalities by liberal economists is rejected by the radical theorist. It is not a problem of paying for unintended consequences of an act. Rather it is a problem of isolated, uncoordinated, disorderly, random capitalist production and consumption system. In a capitalist society peốple are consuming and producing goods and services without taking "into account the untended consequences of their actions. It is a problem of anarchy of production and utilization of environmental resources.

2. The first law of Entropy: This law states that in any given system, you cannot produce a local order in the same system. This law is observable in every activity of man in the environment. A house is an ordered structure (Wisner, 1988). But as an ordered structure, it requires the consumption of materials from somewhere else, namely, from the forest where timber are produced; the ground where iron and other minerals are taken the river where and is lifted, rocks where cement is produced, and the builders themselves need to be fed from energy derived from destroyed food. All of these sources imply destruction of certain features of the environment, if a house is infact to be built.

The maintenance of individuals in the environment also needs the destruction of certain features of the environment. The same is true for building cities, and for building civilization. The trouble is 
not that this law is operative. Rather the trouble is that capitalists disoriented production system supported by increased sophisticated technology and producers and consumers of world resources dominated by capitalism cannot plan systematically for what they consumed and produced in order to allow for replacement and regeneration. In the face of this law, environmental education strategies are shallow and superficial.

3. Second law of Entropy: This law states that any system left to itself tends towards disorganization and decay. Therefore this law suggests that any given constant source of energy tends to organize its units according to system objectives. Our entire environment is such an ecosystem requiring energy from the sun to organize all the processes in it for achievement of ecosystem objectives. But, when man prefers to work in isolation, when he refers to practice extreme individualism, when he interferes randomly in production then, in accordance with this law, he faces increasing environmental disorganization and decay. Problems like desertification, erosion, pollution, flooding, bush burning, and poverty are instances of this law in action.

4. System Order: From the second law of entrophy we arrive at the conclusion that every system requires a system order-forming mechanism. And this implies that every system must be managed. If we raise the question, who is managing the entire ecosystem in the world? We receive the answer: no body in particular. Yet, many books and articles have been written by enviranmertalists on environmental management. Here, the tendency is to apply capitalists management principles to the management of the environmers? But, this is impossible because the isolated production and consumption unit in that system have no generally coordinated plan which makes it impossible to achieve a universal order in the system. By the second Kaw, where local orders have been achieved, local disorders are simultaneously produced (Wisner, 1988; Brown, 1981; Martin, 1988).

Theses four concepts examined here are intended to open our eyes on the serious short-comings of capitalist production and consumption system as a powerful force in the creation of national and international environmental problems.

\section{POLICY OUTPUTS}

Bourgeois economists who write about environmental problems center environmental policy analysis within the framework of interaction of market forces. The approach the problem from the standpoint of market demand or consumption sector. Accordingly, what ever we are producing from the environment is a result of what is demanded from the market. They therefore, regard as distortion any external intervention on the interaction of the market system. But, any policy for environmental management based on bourgeois market forces interaction is bound to fail because there are large areas of environmental human activity where the market does not respond. This is the source of production of externalists. The claim that bourgeois economy is directed by invisible hand of demand and supply or the market forces, decidedly, falls as indicated by the existence of high unemployment, population explosion, increasing poverty 
and under development among African countries. This had let to various ineffective policy strategies like structural adjustment, privatization, commercialization and the so called globalization. These are policies arising from bourgeois assumptions of economic development which merely. serves as a condition for draining African foreign reserve, perpetuation of economic stagnation, dependent structures and persistent environmental disorganization.

In terms of policy, radical political economists insist that not only the socalled morket forces have failed to allocate resources in sustainable manmer within bourgeois economic system, but also bourgeois state continues to be less responsive in polisy matters on envirommental issues. If the bourgeois slate can respond effectively to production and consumption effects of various infustries in the economy, then there will not be so many cases of envirommental disorganization and so much social conflicts as those generated in Delta regions. There is therefore a failture in the eificiency of capitalist market forces and bourgeois state policy assertiveness. (Dear, 1986; 1986a; $1980 \mathrm{~b}$.

\section{CAPABILITIES FOR RADICAL INVOLVEMENT}

Environmental issues and problems have three sides:

a) The physical deterioration and disorganization of the environment arising from various physical activities of man in terms of production and consumption of physical resources. This has to do with unsustainable use of natural resources by man: pollution of rivers, extensive erosion in all its forms, flooding, increasing industrial waste, land use and land ownership that deprive majority of the peasant farm having access to land, and deforestation resulting from extensive logging and over grazing. All of these negative features of the environment arise from man's production and consumption activities within his environment (Evans, 1973).

b) But man does not act physically on the environment in a neutral form. He approaches the environment culturally and ideologically. Therefore the ideas he has about the environment, the skills he has acquired, the values he has internalized all help particular ways. But man is not an abstract entity; he belongs to a particular class in society. Therefore, his knowledge and culture are classoriented. We have workers culture, paasant's culture and rural culture. We also have levels of knowledge associated with different classes of people in the society and the extent of control of resources will indicate significantly the way he will physically use environmental resources. It turns out that while the capitalist class are stressing the environment for production and consumption of resources, they produce extenalities that affect millions and millions of worker and peasant (Backerman, 1972).

c) State respond to negative features of the environment is frequently ambivalent because the state the state would want the negative features to disappear if possible by conjuration, but the state is also committed to economic development as defined by bourgeois economists. The delima faced by those involved in the use and utilization of environmental resources can not therefore be resolved either by the 
bourgeois state or by the bourgeois educational system in the form of environmental education.

It is therefore for this reason that radical theories insist that a dialectical analysis of all the components involved in capitalist production is a precondition for understanding contemporary environmental issues. Furthermore, it is required that complete and systematic coordination of production and redistribution of social resources must be carried out, if the idea of sustainable development will be realistically implemented. Finally, it must be agreed that education is a potent force in the behaviour of men. But bourgeois educational system is oriented towards reenforcement of bourgeois values: monopolization of resources, marginalization of vast population from having access to means to life, primitive accumulation and consumption of resources and terrible lack of concern for the suffering of the entire masses and peasants of Nigeria, are some of the bourgeois values that must first be attacked by the educational system and changed by political and revolutionary neither develop environmental awareness nor change environmental behaviour of those who are already taken prisoner by bourgeois ideology.

\section{CONCLUSION}

In this paper an attempt has been made to describe political economy approach to understanding of environmental issues and problems. It has been shown that, the mode of production of material resources and the relation of production in the means of production is fundamental in understanding the sources of environmental problems. The radical theory had insisted that behind environmental disorganization, the mode of producing surplus value, the form of distributing surplus value among population engaged in production, the amount of surplus value shared by various groups and classes in society, the type of technology employed in productive processes and the control of what is to be produced and what is to be consumed are important variables in understanding why environmental issues persist in capitalist society. It was also shown that it is an inherent feature of capitalism for the market system to fail to allocate resources and for governmental policy to also fail to respond effectively to environmental problems because of competitive vested interests of those who control the means of production.

In the face of marginalization the majority of the people in capitalist society have virtually no alternative than to fall back on the decreasing resources in the environment and exploit the same intensively leading to further environmental disorganization. It is suggested that bourgeois environmental educational system because of shamefaced approach to environmental issues and its shallow concern to trivial factors like environmental awareness should be abandoned in favour of systematic and coordinated reorganization of production, distribution, exchange and consumption of material resources in the ecosystem.

\section{REFERENCES}

Abalkin, L; Dzaurasov, S; and Kulikov. A. (Political Economy: A Short Course, Moscow:

Beckerman, W, 1972. The Myth of Environmental Catastrophe, The National Review, Nov, 24.

Boserup, E., 1996. Development Theory: An Analytical Framework and Selected Applications. Population and Development Review: 4 - 8 .

Bongaarts, J., 1996. Population Pressure and the Food Supply System in the Developing World. Population and Development Revicw pp. $483-503$.

Brown, L. R., 1981. Word Population Growth, Soil Erosion, and Flood Security, Science, Vol. 214. Pp 995 1001 . 
Colin, L. and Roy, W. [18 $\}$ Education. Ecology and Developmen. London: W. W. F. Publications.

Dear, M. (ed). 1986, Special issues on Los Angeles. Fnvironment and Planning $D$. Sociely and Spacc. $2 / 3 \cdot 10-16$

Dear, M. (cd), 1980. Urbanization and Uban Planning in a Capitalist Socicty. London. Macmillan Publishing. Co.

Dumont. R. 1988. False Start in Africa, London, Earthscan Publication Lfd.

Evans, Stanton, M., 1973. Environnucntalists Contribute to Energy Crisis, Human Events May 26. Pp. 434.

Goldtab, T. D., 1997. Taking sides: Emirommental Issues. Now York: Dushkin/Mcciaw-Hill, Inc.

Jones, A L... 1972. A Question of Fcology. Vital Specches. April 1. Pp. 381 …383.

Johnston. R. J. and Taylor, P, J. . 1989. (cds). A World in risis. Oxford: Blackenll.

Lipset. M., 1960. Political Management. New York: The Free Press Marx K. (1973): Grundrisse: Foundations of the Critique of Political Economy Hamondsworth: Pengulin.

Marx, K. , 1976. Capital, Volume 1. Harmondsworth: Martin, R 1. (1988): The Policitical Econony of British Geographers NS13, pp. 389-A18.
Meadows, D. H., 1972. The L.imits to Growth: A Report of the Club of Rome. Now York: Universe Books.

Picket, J. and Singer, J1, 1990. (cds) Tmvards EcomomicRecovery in Sub-Shabaran Africa Innd. Routledge Lid.

Reitman. H. J. A. 1982. Development Geography. Dependency Relations and the Capialist Scapegont. The Professional Geographer, pp. 34. $125-130$.

Samurtson. 1083. Fonomics. New York: Macmillam Publishing ( 0. ld

Samor, 1., 109\% (col) Coping with Crisis: Austents Admentuent and Human Resonros. Non Yuk

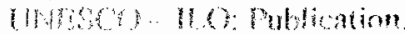

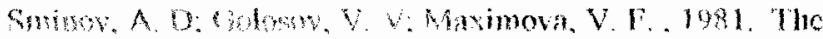
Tcachisy of Politial Ecomony Marxian Thoorics Morom Promes Fontishers.

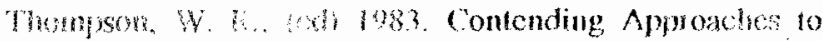
Word Sygtoms Amalysis. London: Macmillan.

Wattenbrg. B. 1970. The Nonsense Explosion. The New Remullic. April i\& \& 11. pp. $18-23$.

Winsner. B. 1988. Power and Need in Africa: Basic Muman Needs and Development Policics, I, nndon: Earthscan Publication Iat. 